\title{
Kritiskt tänkande i forskarutbildningen - handledares röster om ett betydelsefullt examensmål
}

\author{
Magdalena Bexell, Sara Kalm* \\ Statsvetenskapliga institutionen, Lunds universitet
}

\begin{abstract}
Kritiskt tänkande är ett centralt mål för forskarutbildning och annan högre utbildning. Ändå saknas en enhetlig och allmänt vedertagen definition av detta mål. I denna artikel undersöker vi uppfattningar hos forskarhandledare i statsvetenskap om vad kritiskt tänkande är, samt hur de ser på förutsättningarna för kritiskt tänkande som ett moment i forskarutbildningens praktik. I intervjuerna framkommer att det finns en samsyn kring vad som är kärnan i kritiskt tänkande, men att somliga därutöver ger begreppet en utökad innebörd. Skillnaderna i synsätt verkar framför allt ha att göra med vetenskapsteoretisk orientering. Vad gäller uppfattningarna om kritiskt tänkande i forskarutbildningens praktik menar alla att det kritiska tänkandet är utsatt för hot från olika håll. Det finns dock en skillnad i att vissa betonar hot på institutionsnivå medan andra snarare betonar strukturella faktorer som regelsystem och finansieringsramar. Vi menar att det inte är önskvärt att försöka tvinga fram något gemensamt synsätt, men att det är viktigt att påvisa existerande skillnader i syfte att underlätta diskussioner och synliggöra tolkningsutrymmet för detta examensmål. Genom att även belysa de konkreta förutsättningarna för att lära ut kritiskt tänkande talar vår artikel dels till en akademisk litteratur om kritiskt tänkande i högre utbildning, dels till en aktuell debatt om universitetets roll och villkor.
\end{abstract}

Nyckelord: kritiskt tänkande; forskarutbildning; självständighet; kreativitet; marknadisering

\section{INLEDNING}

Att tänka och förhålla sig kritiskt framhålls som ett centralt mål för högre utbildning. Högskolelagen anger att utbildningen på grundnivå (bl.a.) syftar till att "utveckla studenternas förmåga att göra självständiga och kritiska bedömningar" (Högskolelagen I992, I kap, 8\$). I examensordningen för forskarutbildningen är målen som berör "färdighet och förmåga" att doktoranden ska "visa förmåga till vetenskaplig analys och syntes samt till självständig kritisk granskning och bedömning av nya och komplexa företeelser, frågeställningar och situationer" samt "visa förmåga att kritiskt, självständigt, kreativt och med vetenskaplig noggrannhet identifiera och formulera frågeställningar samt att planera och med adekvata metoder bedriva forskning och andra kvalificerade uppgifter inom givna tidsramar och att granska och värdera sådant arbete” (Högskoleförordningen 1993, Bilaga 2). Dessa ambitioner återspeglas i de allmänna studieplanerna för svenska forskarutbildningar i statsvetenskap där en av målsättningarna är att utbilda självständiga och kritiska forskare (Statsvetenskapliga institutionen Lund, 20ı6; Statsvetenskapliga institutionen Stockholm, 20I5; Statsvetenskapliga institutionen Uppsala, 20I2).

\footnotetext{
*Författarkontakt: Sara Kalm, sara.kalm@svet.lu.se

Artiklar och reflektioner är kollegialt granskade. Övriga bidragstyper granskas av redaktionen. Se www.hogreutbildning.se ISSN 2000-7558

(C)2017 Bexell, Magdalena \& Sara Kalm. This is an Open Access article distributed under the terms of the Creative Commons Attribution-NonCommercial 4.0 International License (https://creativecommons.org/licenses/by-nc/4.0/), allowing third parties to share their work (copy, distribute, transmit) and to adapt it, under the condition that the authors are given credit, that the work is not used for commercial purposes, and that in the event of reuse or distribution, the terms of this license are made clear.

Citation: Magdalena Bexell \& Sara Kalm (2017) «Kritiskt tänkande i forskarutbildningen - handledares röster om ett betydelsefullt examensmål»,

Högre utbildning 7(2), 1-17. http://dx.doi.org/10.23865/hu.v7.1026
} 
Kritiskt tänkande betraktas alltså som något som kan läras ut, och som doktorander och studenter kan tillägna sig. Därför är det anmärkningsvärt att det inte finns någon allmänt vedertagen definition av begreppet i styrdokumenten för högskolan. Oavsett om detta är ett medvetet val eller ej gör frånvaron av tydlig begreppsbestämning att utrymmet för tolkningar breddas när det ska omsättas i praktiken - till exempel i kursplaner, handledning och examination av forskarutbildningskurser och avhandlingar. Ytterligare en försvårande omständighet är att det inte heller finns någon allmänt vedertagen definition utanför svensk högskolebyråkrati. Litteraturen på området visar att begreppet kritiskt tänkande är polysemiskt, dvs. att det tillskrivs olika mening av olika personer och i olika kontexter (Croft \& Cruse 2004: 109). Mot denna bakgrund är det viktigt att undersöka hur forskarhandledare ser på kritiskt tänkande. Doktorander bör kunna få veta vad som närmare avses med ett av de centrala målen för deras utbildning om de ska kunna bli "det kritiska tänkandets professionella utförare" (Ankarloo \& Friberg 20I2: Io).

I denna artikel undersöker vi uppfattningar om vad kritiskt tänkande är hos forskarhandledare på Statsvetenskapliga institutionen i Lund - vår egen arbetsplats - och hur kritiskt tänkande kommer till uttryck som ett inslag i forskarutbildningens praktik. Vår erfarenhet säger oss att olika personer vid institutionen lägger in olika innebörd i begreppet, men eftersom kritiskt tänkande, i likhet med andra mål i examensordningen, sällan diskuteras explicit så blir dessa skillnader inte tydligt artikulerade. Att finna betydelsemässiga skillnader och likheter är därför ett övergripande syfte med artikeln liksom att bidra till förståelsen av kritiskt tänkande i akademisk praktik i just en samhällsvetenskaplig kontext.

Litteraturen om kritiskt tänkande domineras av begreppsliga och normativa bidrag som utreder hur kritiskt tänkande kan och bör förstås. Vissa forskare hanterar avsaknaden av en allmänt accepterad och enhetlig definition genom att försöka ta fram en sådan definition och argumentera för att den är att föredra framför andra (Ennis 20I5; Siegel 1988). Vår ambition är alltså istället empirisk i det att vi försöker kartlägga och förklara bakgrunden till skillnader i synsätt utan att fälla något eget omdöme om vilket definition som är att föredra (jfr Moore 20I3; Brodin 20I6a). Genom detta bidrar vi till att öka kunskapen om hur faktiskt existerande uppfattningar om kritiskt tänkande ser ut, vilket kan jämföras med motsvarande uppfattningar $i$ andra ämnen, på andra universitet och i andra länder.

Vi har tre specifika frågeställningar. De första två är beskrivande och besvaras med hjälp av intervjumaterial; den sista är mer analytisk och förklarande i sin ambition och besvaras främst i slutsatserna: (I) Vilka uppfattningar om kritiskt tänkande har handledare inom forskarutbildningen vid Statsvetenskapliga institutionen i Lund? (2) Hur ser dessa handledare på förutsättningarna att i praktiken lära ut och examinera kritiskt tänkande på forskarutbildningen? (3) I vilken utsträckning skiljer sig uppfattningarna om kritiskt tänkande åt, och vad kan detta bero på?

Genom att belysa de konkreta förutsättningarna för att lära ut kritiskt tänkande talar vår uppsats dels till en akademisk litteratur om kritiskt tänkande i högre utbildning (se t.ex. Davies och Barnett 20I5), dels till en aktuell debatt om universitetets roll och villkor. Det kritiska idealet präglar ju traditionellt även uppfattningen om universitetets uppgift. I en statlig utredning förklaras det exempelvis att "[h]ögskolan ska utgöra en kritisk kraft i samhället", och att: "Som myndighet är högskolan unik i sitt uppdrag att vara en nagel i ögat på sin uppdragsgivare" (SOU 20I5: 70, s. 236). På senare år har universitetets möjligheter att utgöra denna "kritiska kraft" emellertid kringskurits, menar många forskare, som bl.a. pekar på förändrade finansieringsstrukturer, styrformer och ideal, och dessas konsekvenser för forskningens oberoende (Rider 
m.fl. 20I3; Hasselberg 20I2). I Den högre utbildningen. Ett fält av marknad och politik (Ankarloo \& Friberg 20I2) hävdar författarna att de institutionella förutsättningarna för universiteten urholkas genom den högre utbildningens politiska, organisatoriska och pedagogiska förändringar. I förlängningen riskerar universitetslärare, doktorander och studenter att omformas till något annat än kritiska tänkare (se också Ahlbäck Öberg m.fl. 2016). Debatten visar på ännu ett skäl till att det är viktigt att forska om kritiskt tänkande såsom det uppfattas och hanteras i forskarutbildningens verksamhet - nämligen att bidra till att värna högskolans oberoende genom att identifiera utmaningar eller till och med hot mot sådant tänkande.

Nedan följer en diskussion om metod och material. I de nästföljande avsnitten redovisar och analyserar vi resultaten av intervjustudien. I ett första steg beskriver vi där vilka olika uppfattningar om kritiskt tänkande vi har identifierat på institutionen. I ett andra steg beskriver vi hur handledare ser på förutsättningarna att lära ut kritiskt tänkande i forskarutbildningen. I avslutningen resonerar vi kring förklaringar till samsyn och olikheter.

\section{METOD OCH MATERIAL}

Urval

Vårt empiriska material består av intervjuer med tretton personer verksamma inom forskarutbildningen i statsvetenskap vid Lunds universitet (se Bilaga). Vi har koncentrerat oss på personer som har gedigen erfarenhet av forskarutbildningen. Våra intervjupersoner har alla handlett doktorander, många av dem ett flertal, och i flera fall har de undervisat på kurser på doktorandnivå. Sju av våra intervjupersoner är professorer och tre docenter. Övriga tre är universitetslektorer som har lång erfarenhet av att handleda och även på andra sätt medverka i forskarutbildningen. Tre har varit studierektor för forskarutbildningen och en för grundutbildningen, en har erfarenhet av biträdande prefektskap med arbetsgivaransvar för doktorander.

Vid urvalet har vi också eftersträvat viss variation för att fånga upp olika synsätt på kritiskt tänkande. Vårt urval baseras på tre faktorer vi tror skulle kunna påverka synen på kritiskt tänkande. Vi har för det första velat ha variation ifråga om vetenskapsteoretisk orientering. Därför har vi inkluderat både forskare inom den rationalistiska eller positivistiska traditionen och dem som rör sig mot kritisk teori eller poststrukturalism. Vi är inte säkra på att denna faktor är lika relevant på alla fakulteter, men inom samhällsvetenskap är den avgjort det. Att vetenskapsteoretisk orientering är viktigt i detta sammanhang verkar ganska självklart, eftersom det har att göra med generell vetenskapssyn. Här vore det istället förvånande om det inte gav något utslag. Nedan kallar vi våra två kategorier "positivister" (P) respektive "postpositivister" (PP) och vi är medvetna om att det är möjligt att både kategorierna (P/PP) och själva indelningen skulle kunna ifrågasättas. För vårt begränsade syfte i denna uppsats menar vi att den grovhuggna kategoriseringen är tillräcklig. Vad gäller indelningen så gick den till så att varje person placerades i enbart en av kategorierna. Denna kategorisering var i somliga fall lätt och, tror vi, i överensstämmelse med våra kollegors självuppfattning. Några var mer gränsfall och därför svårare att kategorisera.

1 Vi följer Yosef Lapids inflytelserika kategorisering inom ämnet internationell politik (Lapid I989). Metateoretisk orientering är ett känsligt område inom statsvetenskapen, och det har gett upphov till många metodstrider och andra heta debatter. Det finns ett flertal sätt att dela in det, men detta är inte rätt plats att gå in mer på djupet på detta (se t.ex. Booth \& Smith 1995). 


\section{Magdalena Bexell \& Sara Kalm}

För det andra har vi velat ha med forskare från olika subdiscipliner. Därför finns bland våra intervjupersoner representanter för var och en av statsvetenskapens breda underavdelningar: politisk teori, svensk och jämförande politik, förvaltning och internationell politik. Flera forskare rör sig i praktiken i gränslandet mellan olika fält, och har då fått mer än en etikett. Tanken här är att expertorienterade professionella nätverk eller kunskapsgemenskaper skulle kunna vara viktiga för att forma en forskares synsätt (jfr Haas 1992).

Det finns också faktorer som talar för samsyn snarare än olikhet. Man kan tänka sig att institutionen utgör ett slags "praxisgemenskap" med likartad syn på för verksamheten centrala begrepp som kritiskt tänkande. En praxisgemenskap är en samhörighet med drag av kollektiv identitet som uppstår när man arbetar tillsammans och i detta interagerar regelbundet och ofta (Wenger-Trayner \& Wenger-Trayner 2015). Men man skulle också kunna tänka sig att kritiskt tänkande är så fundamentalt för den västerländska vetenskapskulturen att det finns en grundläggande samsyn som går långt utöver institution och ämnesinriktning. Man kan tala om ett slags "doxa", dvs. ett djupt liggande gemensamt sätt att se på forskningens och vetenskapens roll som överskrider disciplingränser och andra skillnader (Bourdieu 2000: 10). Detta skulle kunna yttra sig i ett gemensamt förhållningssätt på ett grundläggande plan, som kan samexistera med skilda uppfattningar på ytplanet. Vår förhoppning är att vårt urval gör det möjligt för oss att fånga upp både skillnader och likheter och att resonera om tänkbara anledningar.

\section{Intervjuguide och frägor}

När intervjupersonerna tillfrågades fick de reda på det övergripande temat, men inte de specifika frågorna. Samtliga intervjuer genomfördes under april och maj 20I6, en av dem via Skype. Vi utförde intervjuerna en och en, ungefär hälften var. Varje intervju varade i cirka trettio minuter och samtliga spelades in. Intervjuerna var av semistrukturerad karaktär. Vi hade en intervjuguide med frågor, men dessa var öppna och intervjuerna tog formen av samtal där frågorna behandlades i lite varierande ordning (jfr Kvale 1997: 12I). Intervjuerna delades in i två teman som korresponderade med forskningsfrågorna (I) och (2) (se ovan). Det första syftade till att ringa in hur intervjupersonen definierade kritiskt tänkande och det andra behandlade förutsättningarna för att lära ut det på forskarutbildningen. I vissa frågor var vi ute efter resonemang, i andra erfarenheter och i åter andra åsikter (jfr Kvale 1997: 124-125). Vi utgick ifrån att inte alla skulle ha en alldeles genomtänkt och färdigformulerad syn på vad kritiskt tänkande är (vilket också visade sig stämma), och ställde därför flera frågor på lite olika sätt för att på så sätt försöka ringa in deras uppfattningar (Ic-f). För dem som hade en genomtänkt syn var dessa "stödfrågor" mindre viktiga, men för dem som var mer trevande var de flera gånger till stor hjälp. Frågorna som ställdes vid intervjuerna var:

\section{Tema I: Hur definieras kritiskt tänkande?}

a. Vad innebär "kritiskt tänkande" för dig?

b. Hur viktigt är kritiskt tänkande för dig i din roll som handledare och lärare?

c. Hur känner man igen resultatet av kritiskt tänkande när man ser det?

d. Vad skulle motsatsen till kritiskt tänkande kunna vara?

e. Vad är förhållandet mellan kritisk forskning och bra forskning? Synonymt?

f. Är kritiskt tänkande ett attityd-, färdighets- eller kunskapsmål? 


\section{Tema 2: Vilka förutsättningar finns för att lära ut kritiskt tänkande under FU?}

a. Hur ser du på förutsättningarna för att lära ut kritiskt tänkande i forskarutbildningen?

b. Hur görs detta i praktiken? Hur skulle det kunna göras?

c. Hur examineras kritiskt tänkande?

d. Vilken roll har handledaren i att lära ut kritiskt tänkande? Ligger ansvaret för att detta mål nås där eller någon annanstans?

e. Finns det något som hotar undervisningen och inlärningen av kritiskt tänkande?

\section{Hur vi hanterar och forstår olika betydelser i intervjuerna}

Vi har tidigare nämnt att begreppet kritiskt tänkande är polysemiskt eftersom det tillskrivs många olika meningsinnehåll. Men utfallsrummet av möjliga meningsinnehåll är inte hur brett som helst, och olika definitioner är inte slumpmässigt relaterade till varandra. Inom kognitiv lingvistik menar man att meningsspridningen hos polysemiska ord $i$ allmänhet sker inom avgränsade fält i det vidare språkliga och begreppsliga rummet. Varje individuell uppfattning kan ses som en punkt inom dessa metaforiska fält. Inom fältet är inte meningsbildningen kontinuerlig utan ojämnt grupperad i formationer med avstånd emellan. Olika sådana formationer är olika framträdande och olika väl inre sammanhängande (Croft \& Cruse 2004: IO9-III).

I vårt specifika fall sker betydelsebildningen inom det avgränsade fält som utgörs av en djupt rotad universitetskultur å ena sidan och samhällsvetenskapligt tänkande å andra sidan. Dessa är inte enhetliga storheter, men markerar tillsammans gränserna för det möjliga utfallsrummet. Vi föreställer oss att var och en som varit verksam inom universitetet under en längre period har mottagit och formats av vissa universitetskulturella ramar (där graden av individuell medvetenhet varierat), där möjliga tolkningar av kärnvärdet kritiskt tänkande varit en del. Detta tror vi gäller oavsett ämne och fakultet. Vi föreställer oss vidare att samhällsvetenskap skiljer sig från andra ämnesfält på så sätt att floran av synsätt på kritiskt tänkande i hög grad avspeglar existerande skiljelinjer inom samhällsvetenskapen. Utvecklingen av tänkandet om kritiskt tänkande, vilken främst skett inom filosofi och pedagogik, har skett parallellt med utvecklingen inom samhällsvetenskapen i stort. Därför tenderar skillnader i synsätt beträffande kritiskt tänkande reflektera viktiga existerande skiljelinjer inom samhällsvetenskapen, både vad gäller synen på god vetenskap och synen på vad t.ex. makt är för någonting. Det torde därför finnas en viss korrespondens mellan existerande synsätt på kritiskt tänkande och de perspektiv och positioner som finns inom statsvetenskapens (eller samhällsvetenskapens) fält. Fält ska här förstås i Bourdieus mening, dvs. som ett avgränsat system av relationer mellan positioner där olika aktörer kämpar om olika symboliska och materiella värden. Konstformer och akademiska discipliner har typiskt karaktären av sådana fält (jfr Broady 1988: 5-6). Framför allt utmärks fält av att det ytterst är något för alla aktörer gemensamt som står på spel. I vårt fall handlar detta om vad som ska räknas som god statsvetenskap.

Vi kommer nu att ge en kort bakgrund till den teoretiska utvecklingen på området kritiskt tänkande, inklusive vilka huvudsakliga skillnader vi kan se idag². Davies och Barnett urskiljer härvidlag tre rivaliserande perspektiv, som är oense om både vad man riktar sin kritik emot och vad kritik egentligen innebär (Davies \& Barnett 20I5: 6-7): Det analytisk-filosofiska perspektivet var

2 För en mer uttömmande översikt, se Brodin 20I6b. 


\section{Magdalena Bexell \& Sara Kalm}

länge ensamt dominerande. Det ser kritiskt tänkande som en färdighet i fråga om att konstruera och utvärdera argument utifrån kriterier om logik och konsistens, validitet och reliabilitet (Facione I990; Bowell \& Kemp 20I5). Under 1980-talet växte utbildningsperspektivet fram under inflytande av bland annat pedagogik, psykologi och kognitionsstudier. Det sätter individens personliga utveckling i centrum och vill lära ut en särskild kritisk attityd, ett sätt att vara. Därför vidgar man innebörden av begreppet till att innefatta känslor, intuitioner och kreativitet. Aktivistperspektivet växte fram under samma period och har sina rötter i kritisk teori, marxism och psykoanalys i västvärlden. Detta vill blottlägga dolda maktstrukturer för att på så sätt bidra till människans frigörelse, och därför betonas vikten av politisk handling som förknippat med kritiskt tänkande (Brookfield 20I5). Till dessa vill vi lägga ytterligare två perspektiv, som också är vanligt förekommande i litteraturen: det reflexiva perspektivet och det holistiska perspektivet. Det reflexiva perspektivet härrör från poststrukturalismen och dennas kritik mot uppfattningen om objektiva kunskapskriterier. I likhet med aktivistperspektivet vill man förhålla sig till sin samtid, men man gör det genom att undersöka möjlighetsbetingelserna för vår kunskap om denna. Då man menar att forskaren inte kan ställa sig utanför sin tid eller kultur, så räcker det inte att rikta kritik mot "externa" maktstrukturer (Butler 2009; Geuss 2002; Foucault 20II). Kritik inbegriper därför alltid självkritik: "ett tänkande där tänkaren granskar förutsättningarna för sin egen tankeverksamhet" (Rider, citerad i Brännström 20II). Det holistiska perspektivet, slutligen, vill å sin sida fånga upp många olika betydelser av kritiskt tänkande, som exempelvis kunskapskritik, reflektion och handling. Målet för högre utbildning blir då att integrera de olika beståndsdelarna för att främja utvecklingen av "en kritisk varelse" (Barnett 20I5; Curzon-Hobson 2003).

I vår analys har vi ringat in fyra huvudsakliga betydelser som de intervjuade handledarna ger kritiskt tänkande (se nedan). Vi har gått induktivt snarare än deduktivt tillväga, och velat fånga hur våra respondenter formulerat sig snarare än att placera in deras uttalanden i förutbestämda kategorier. Trots detta har vi upptäckt ganska stora likheter med de här omnämnda perspektiven. Vi ser tydliga kopplingar mellan de uppfattningar vi finner hos handledarna och det analytisk-filosofiska, det aktivistiska och det reflexiva perspektivet. Anledningen till detta finner vi, som ovan nämnts, i den parallella utvecklingen av samhällsvetenskapen och idéer om kritiskt tänkande. Som kommer att framgå nedan ser vi ingen koppling till det holistiska perspektivet och en ytterst partiell koppling till utbildningsperspektivet. Det skulle vara intressant att veta om andra samhällsvetenskapliga discipliner skiljer sig ifråga om detta.

Det är viktigt att inte se våra identifierade betydelser, eller våra intervjupersoner, som representanter för något särskilt teoretiskt perspektiv. Det är möjligt att somliga skulle identifiera sig med något av dem, men detta ligger utanför vår studie. Våra informanter är inte noviser på området eftersom de vistats länge i miljön och som forskare tillägnat sig uppfattningar som på viktiga sätt berör vad kritiskt tänkande är. Men de är inte heller experter på kritiskt tänkande som eget forskningsområde. Intervjusvaren är därför ofta mångfaldiga och inte helt sammanhängande, de är fragmentariska och de hämtar som regel näring ur flera av de rådande perspektiven. Därför har vi ofta gett våra intervjupersoner fler än en etikett (se Bilaga).

\section{UPPFATTNINGAR OM KRITISKT TÄNKANDE}

I detta avsnitt presenterar och analyserar vi de intervjuade handledarnas uppfattningar om kritiskt tänkande. De huvudsakliga betydelser vi identifierat kallar vi för "Skepsis och granskning", "Kreativitet och självständighet", "Avtäcka maktstrukturer" samt "Reflexiv självkritik". 
Skepsis och granskning

Att sätta skepsis och granskning i centrum för vad kritiskt tänkande handlar om har tydliga kopplingar till det analytisk-filosofiska perspektivet och var allra vanligast förekommande. Det som ska utsättas för skepsis och granskning är hela den process som har lett fram till de slutsatser en författare drar. "I normativa analyser ställer vi krav på argumentationen, logik-konsistens och argumentens styrka. I empirisk forskning ställer vi krav på belägg för det som hävdas, alltså evidens" (G). För att en text ska hålla en bra vetenskaplig nivå måste alla delar av processen kunna utsättas för granskning. Detta innebär både att texten är öppen och transparent och att man kan se att författaren övervägt alla steg på vägen. "Man känner igen kritiskt tänkande på att författaren har tänkt på allt” (K).

Detta kokar i allt väsentligt ner till en fråga om medvetenhet. Just denna term, medvetenhet och dess motsats omedvetenhet, användes flitigt av våra intervjupersoner - och särskilt när de talade om skepsis och granskning. "Brist på kritiskt tänkande är när man påstår saker utan att visa dem, att man gör påståenden utan att vara medveten om att det man säger inte är självklart. Dåliga texter kännetecknas av att folk upprepar fraser utan att riktigt tänka igenom vad påståendena betyder. Motsatsen till kritiskt tänkande är alltså omedvetenhet" (K, även A, I). Fler resonerar i liknande banor. På frågan om vad motsatsen till kritiskt tänkande är framhåller många av våra intervjupersoner omedvetenhet, auktoritetstroende och oreflekterad passivitet $(G, D)$.

Alla utom en av dem som vi klassificerat som "P" gav explicit uttryck för detta synsätt. Även de flesta i PP-gruppen har framhållit det. Vikten av medvetenhet och av att granska giltigheten av påståenden är exempel på sådant som lyfts fram av personer även i denna grupp (B, F). Som någon av dem uttryckte det: "Allmän kritisk granskning ska vi ju alla ägna oss åt, det är ju definition på forskning" (L). En annan sade att oavsett vetenskapsteoretiskt ställningstagande måste man uppvisa kritiskt tänkande i "generell bemärkelse", vilket då innefattar ett medvetet förhållningssätt både till tidigare forskning och till de metoder och teorier man själv väljer (J). Det framstår därför för oss som om det på ett grundläggande plan råder stor enighet om de värden som "skepsis och granskning" uttrycker.

\section{Kreativitet och själuständighet}

Att betona kreativitet och självständighet som centrala element i kritiskt tänkande var nästan lika vanligt som det föregående. Detta har beröringspunkter med det som ovan kallats utbildningsperspektivet, men är mycket mer begränsat.

Nästan alla lyfte fram att det är viktigt att göra ett självständigt bidrag till forskningen. Att vara kreativ och ha egna idéer och att tillföra något till den existerande litteraturen, driva vetenskapen framåt, betraktas som centralt $(\mathrm{M})$. Flera menade också att det är en central del av handledningen att uppmuntra doktoranden att lösa problem på ett självständigt sätt (I). För att kunna göra ett ordentligt bidrag, menade flera, är det nödvändigt att också ha en god överblick över sitt forskningsområde: kunskaper är alltså en förutsättning för självständighet (J). Någon uttryckte det som att "man måste vara konservativ och radikal samtidigt. Radikal i att vilja prova nytt och ifrågasätta gamla sanningar. Konservativ i det att inte uppfinna hjulet" (G). Detta tar sig uttryck i att man dels förmår positionera sig emot en del tidigare forskning, dels vet hur man ska välja vilken litteratur man själv ska luta sig emot (D). Kunskapsdimensionen gör att det nästan krävs att läsaren också är insatt i litteraturen för att kunna bedöma graden av kritiskt tänkande, förstått som självständighet (D). 
Liksom "skepsis och granskning" är "kreativitet och självständighet" något som värderas väldigt brett". De huvudsakliga betydelser vi identifierat kallar vi för: nästanär "kreativitet och självständighet" något som värderas väldigt brett. Dessa framstår nog för de flesta som okontroversiella eftersom de är kvaliteter som vi undervisar i, och undervisas i, redan från grundutbildningen - kanske redan från gymnasiet, som någon påpekade $(G)$. Personer från både $P$ och PP-grupperna framhöll detta, vilket tyder på att de speglar ett djupt liggande förhållningssätt.

Trots att det är sådant som alla värderar vill vi dock framhålla att det inte är självklart för alla att de går in just under benämningen kritiskt tänkande. En intervjuperson reserverade termen kritiskt tänkande för det som vi här benämner skepsis och granskning. Denne menade att kritiskt tänkande i denna mening är en nödvändig men inte tillräcklig förutsättning för god forskning: för detta krävs dessutom att man gör ett självständigt bidrag $(\mathrm{K})^{3}$. För andra var det istället så att kritiskt tänkande var synonymt med självständighet (D, G). Någon ser avsaknad av egna idéer och eget bidrag som motsatsen till kritiskt tänkande (I).

\section{Avtäcka maktstrukturer}

Medan våra handledare från både P- och PP-gruppen ser de ovan nämnda värdena som viktiga komponenter i kritiskt tänkande, så är det enbart folk ur PP-gruppen som går vidare och också ger kritiskt tänkande en extra betydelse. Denna kan då vara antingen i linje med "avtäcka maktstrukturer", som ska behandlas här, eller "reflexiv självkritik", som behandlas i nästa avsnitt. Skillnaden ligger i att betona yttre maktstrukturer eller kritikens egna gränser, inklusive det egna tänkandet.

När kritiskt tänkande förstås som en fråga om att "avtäcka maktstrukturer" kan man se en korrespondens med aktivistperspektivet. Inom statsvetenskapen (särskilt internationell politik) är Robert W. Cox' åtskillnad mellan "problemlösande" och "kritisk forskning" välkänd. Cox menade att problemlösande forskning tenderar att ta existerande institutioner och maktrelationer för givna, och syftar till att förbättra inom dessa givna ramverk. Kritisk forskning tar inte dessa ramverk för givna utan vill ifrågasätta dem, undersöka hur de kom till stånd och vilka maktförhållanden de cementerar (Cox I98r: I28-9). Uppdelningen mellan problemlösande och kritiskt speglar i mångt och mycket uppdelningen mellan det vi här kallar positivism och postpositivism. Kritisk forskning, i Cox’ mening, kan bedrivas utifrån t.ex. vissa feministiska, gröna, postkoloniala och nymarxistiska perspektiv (Alvesson och Deetz 2000; Lapid 1989). Att vi nämner Cox här beror på att många av våra intervjupersoner spontant hänvisade till denna distinktion.

Vissa postpositivister sticker ut genom att ange motsatsen till kritiskt tänkande framför allt i termer av andra angreppssätt än deras egna. Till exempel nämner en handledare att motsatsen till kritiskt tänkande i första hand är hävdandet av en förment neutral position, vilket handledaren benämner positivism (B). En annan postpositivist betonar med hänvisning till Cox att motsatsen är "problemlösande" forskning (F). En tredje uttrycker motsatsen till kritiskt tänkande så

3 Detta ligger för övrigt i linje med hur centrala representanter för det analytisk-filosofiska perspektivet resonerar. "CT [Critical Thinking] is one among a family of closely related forms of higher-order thinking, along with, for example, problem-solving, decision making, and creative thinking. The complex relationships among the forms of higher-order thinking have yet to be examined satisfactorily" (Facione I990: 5). 
här: "Att man tror att man kan återskapa, återge verkligheten med bara en röst, utan den kritiskt reflekterande delen mellan det man ser i verkligheten och det man skriver" (L).

Synen på kritiskt tänkande som att "avtäcka maktstrukturer" är utan tvekan den mest omtvistade. En person omfamnade uttryckligen denna betydelse av kritiskt tänkande. Denne talade om behovet av att ifrågasätta dominerande diskurser, att det som betraktas som "normalt" i sig speglar vissa maktförhållanden, och att det är viktigt att förstå att ens position som forskare inte är neutral. Personen framhöll dock att det finns bra forskning som inte är kritisk i den här betydelsen (B). Flera av intervjupersonerna ville dock distansera sig från den tolkning av kritik som kommer med detta synsätt. Någon framhöll att det finns många andra sätt att bedriva god och medveten forskning (A). En handledare pekade på att det inom den kritiska traditionen finns en viss etablerad framställningsform som explicitgör metateoretiska reflektioner. Att så inte är fallet i annan - mer positivistisk - forskning ska inte tolkas som att reflektionerna inte finns där, utan som att skrivgenren är annorlunda (E). Flera lyfte fram att kritisk forskning inte är ensam om att vara kritisk: "Den speciella traditionen 'kritisk forskning' är något särskilt, inte nödvändigtvis kritisk i min mening och inte mer kritisk än andra" $(\mathrm{H})$. "All forskning ska vara kritisk! Inte bara 'kritisk forskning' som i en viss genre" $(G)$. Några framhöll att den kritiska forskningen själv i praktiken kan bli dogmatisk och därmed okritisk (E, F, C).

\section{Reflexiv självkritik}

Medan den kritiska ambition som beskrivs i föregående avsnitt främst gäller att avtäcka yttre maktstrukturer, betonas här även att ifrågasätta själva kritikens utgångspunkter. Detta har likheter med det reflexiva perspektivet i vår teoretiska genomgång. Liksom "avtäcka maktstrukturer" är det yttersta syftet här att ifrågasätta det som vanligen inte problematiseras. Men de som lägger denna betydelse i kritiskt tänkande positionerar sig ofta gentemot det kritiska eller aktivistiska perspektivet enligt vår beskrivning av detta ovan. Någon menade t.ex. att "så kallad kritisk forskning" riskerar att förfalla till "testuggande". Vidare: "Min erfarenhet är att det inte finns för lite kritisk forskning, utan för mycket - av det testuggande slaget". Därför, menar samma person, är det viktigt med självreflexion och att ständigt ifrågasätta kritikens egna grunder $(\mathrm{F})$.

Någon beskriver det som att det kritiska tänkandets främsta uppgift är att granska och ifrågasätta det man tar för givet (L). Ytterligare någon betonar vikten av att "problematisera de antaganden som krävs för att något ska vara giltigt" och att ifrågasätta den position utifrån vilken kritiken riktas (C).

Det går att skönja en koppling mellan det här synsättet på kritiskt tänkande och en viss syn på universitetets uppdrag. Även om det finns mycket god forskning av annat slag, menar en av våra intervjupersoner, är det viktigaste uppdraget för forskningen att "gräva i förutsättningarna för verkligheten som vi ser den" och på det sättet åstadkomma "kritiskt destabiliserande effekter" för tänkandet. Detta är en huvuduppgift för universitetet, och det som skiljer ut den forskning som bedrivs där från den som bedrivs på t.ex. konsultföretag och myndigheter: "Möjligheten att tänka kritiskt och därmed upptäcka nya vinklar och problem är nödvändigt för akademisk frihet, vilket är en förutsättning för intellektuell självständighet” (F). Dock menar samma person att det finns flera sätt att vara kritisk på, och att även forskning av det "problemlösande" slaget gör viktiga bidrag och fungerar som komplement till det personen själv värderar högst. Självständighet och giltighetsprövning är då viktiga inslag. Även här kan vi alltså se hur folk ur 
PP-gruppen också värderar kritiskt tänkande i betydelsen "skepsis och granskning" och "kreativitet och självständighet”.

\section{KRITISKT TÄNKANDE I FORSKARUTBILDNINGENS PRAKTIK}

Våra intervjuer innehöll också frågor om hur kritiskt tänkande kommer till uttryck i forskarutbildningens praktik och vilka eventuella hot handledarna ser mot kritiskt tänkande i det sammanhanget. Vi sammanfattar nedan tre teman som framträdde i handledarnas svar.

\section{Seminariediskussion och perspektivdebatt}

Överlag ser de flesta kritiskt tänkande som högst närvarande i forskarutbildningens praktiska genomförande men inte som ett eget explicit moment: "Det är sällan man lär ut kritiskt tänkande, man har inte kurser i det. Snarare är det ett resultat av allt annat man gör" (H). Det är något underförstått, en implicit del eller resultat av det som görs. Det är inbyggt i systemet, kontinuerlig learning by doing genom kurser, avhandlingsutkast och seminarier och något som följer av att doktoranden befinner sig i en miljö där man läser varandras forskning, där det utbyts argument och där det krävs belägg, menar person $\mathrm{H}$. Här finns i bakgrunden synen på kritisk forskning som "skepsis och granskning" (se ovan).

Frågan om ifall kritiskt tänkande är ett kunskaps-, färdighets- eller attitydmål var intressant på flera sätt. Föreställer man sig att det går att föra över det från lärare till student tänker man sig kritiskt tänkande nästan som ett slags objekt (jfr Lakoff \& Johnson 1980: IO-II). Är det en färdighet man tillägnar sig genom övning föreställer man sig det snarast som ett slags hantverkskunnande, och har det med attityd att göra så är det något som främst verkar kommer inifrån studenten själv. På så sätt avslöjas något om hur man ser på det kritiska tänkandets natur. Det är också tydligt att pedagogikens roll blir olika i vart och ett av de här fallen, om den ska vara aktiv eller passiv och i vilket sammanhang den ska utövas.

De flesta av våra intervjupersoner menar att det finns stora möjligheter att lära ut kritiskt tänkande på forskarutbildningen, åtminstone som en färdighet. Flera menade att kritiskt tänkande kan ses som både ett kunskaps-, färdighets- och attitydmål (D, H, E, G). Någon (F) säger dock att "kritiskt tänkande ska inte läras ut tvångsmässigt, det är emot dess natur". Kritik kommer spontant och naturligt för dem som söker till forskarutbildningen, menar samma person. Man bör inte tvinga doktorander att anamma en "problemlösande" ansats i sitt avhandlingsarbete. Detta bottnar sannolikt i personens övergripande postpositivistiska reflexiva synsätt på vad kritiskt tänkande är (se ovan). Någon talade om kritiskt tänkande som "ett grundtemperament, en attityd, ett förhållningssätt" (E). För ett par stycken var det resultatet av en inre mognadsprocess, alltså en fråga om personlig utveckling och därför svårt att lära ut $(\mathrm{H}, \mathrm{G})$.

Flera menar att institutionens forskningsmiljö skapar goda förutsättningar för att gynna kritiskt tänkande genom seminarieverksamheten och en tolerans för olika perspektiv. "Kritiskt tänkande är seminariets livsluft" (E). En handledare som i huvudsak verkat på institutionen i Lund noterar också att denna tolerans ökat sedan hen var doktorand (B). Flera lyfter dock fram att lågt seminariedeltagande inte gynnar utvecklingen av doktorandernas kritiska tänkande. De menar att man lär sig genom exempel, genom att höra hur andra som är kritiska reflekterar. Eftersom kritiskt tänkande inte har med ämnesinriktning att göra kan det gemensamma forskarseminariet vara centralt för att lära ut sådant tänkande. Det kan också ske i mindre forskargrupper, menar dessa intervjupersoner. 
Medan en person betonar att ämnet statsvetenskap i sig har en substans som skapar ett ifrågasättande oavsett vilken metod man använder (L), är en annan bekymrad över att doktorander redan har bestämt vilken sorts statsvetare de är när de kommer till forskarutbildningen (K). Den senare ser det som ett hinder för kritiskt tänkande att nyantagna doktorander redan är självmedvetna om val av teori, metod $\mathrm{mm}$. Då finns en massa premisser som aldrig prövas på forskarnivå. En annan handledare säger att på forskarutbildningen förutsätts att doktoranderna har funderat över ontologi och epistemologi, att de är bekanta med perspektivseendet och glasögonmetaforen (B).

De som förstår kritiskt tänkande i betydelsen "avtäcka maktstrukturer" betonar att det är viktigt med ett brett vetenskapsteoretiskt anslag på metodkurserna på forskarutbildningen och att det finns lärare med olika perspektiv med. En handledare är bekymrad över att introduktionsåret på forskarutbildningen inte innehållit en balans mellan kritiskt orienterade forskare och andra. Nya doktorander måste få se den spridning som finns på institutionen (L). Några intervjupersoner menar att internationaliseringen av forskarsamhället domineras av en viss vetenskapstradition som inte explicitgör eller premierar kritiskt tänkande (E, L). Effekten av detta är att kritiskt tänkande än mer får karaktären av "tyst kunskap".

Någon menar att det största hotet mot doktoranders kritiska tänkande är en situation där det inte är högt i tak på institutionsnivå. "Att vi delar in oss i olika sorts statsvetenskap där det inte är legitimt att från ett perspektiv kritiskt granska forskning som är framställd av någon med ett annat perspektiv." Personen tycker att institutionens forskarseminarier har kännetecknats av ett sådant problem. Även om det blivit bättre händer det fortfarande alltför sällan att folk möts på ett bra sätt från olika håll. "Många bygger murar runt sin egen typ av forskning, den blir bara relevant för dem som delar ens egna antaganden, men man granskar aldrig dessa antaganden kritiskt" (K).

\section{Ansvar och examination}

Samtliga handledare menade att ansvaret för att lära ut kritiskt tänkande delas av handledaren och institutionsmiljön. Det kollektiva institutionsansvaret praktiseras i form av seminarieaktivitet, manuskonferenser, kurser och grupphandledning. Det kollektiva ansvaret motiveras med att det är viktigt att doktoranden inte blir alltför beroende av en eller två handledare. Institutionen har därtill ansvar för att se till att det finns inslag av metakurser i teori och metod samt för hur man organiserar forskarutbildningen från antagning till disputation.

En intervjuperson, präglad av synen på kritiskt tänkande som skepsis och granskning, menar att handledaren implicit lär ut kritiskt tänkande genom sina kontinuerliga kommentarer på doktorandens texter $(\mathrm{H})$. En annan handledare påpekar att även seniora forskare borde ha mer kontinuerlig bred vetenskaplig diskussion som ett stöd för doktoranderna (M). Någon betonar handledarens ansvar att presentera bredd i litteraturen (B). En färde betonar att det är viktigt att som handledare vara öppen inför ett projekt och att inte driva på för en låsning för tidigt. Handledaren ska hålla tillbaka de yttre kraven på att låsa tidigt och därmed skapa utrymme för ett icke-instrumentellt tänkande. Därtill ska handledaren inte föreställa sig att man är auktoritet utan vägleda i perspektivseende (E).

Det råder också enighet om att kritiskt tänkande outtalat examineras genom alla moment $\mathrm{i}$ forskarutbildningen, som ett element bland många andra. Framför allt ses avhandlingsarbetets olika granskningsstationer som det tydligaste uttrycket för examination av kritiskt tänkande. 


\section{Magdalena Bexell \& Sara Kalm}

"Självständighet, kritiskt tänkande - tecken på bra avhandling" (G). "Avhandlingen ska avspegla den mogenhet som finns i kritiskt tänkande" (E). Flera lyfter fram att kritiskt tänkande är något vi bedömer och examinerar redan på grundutbildningen genom dess krav på självständighet och medvetna val av begrepp och metod.

Det finns alltså en grundläggande samsyn kring ansvar och examination av kritiskt tänkande som ett element i forskarutbildningen i statsvetenskap. Några intervjupersoner framhöll därtill olika examinationsrelaterade utmaningar för doktoranders kritiska tänkande. En handledare menar att självständigheten hos både doktorand och handledare undermineras genom att ansvaret tas ifrån handledaren i allt högre grad och flyttas ut i miljön till andra bedömare. Detta sker på institutionsnivå genom att manuskonferensen i slutskedet av avhandlingsarbetet blivit mindre öppen. Från att ha haft formen av ett öppet allmänt seminarium på institutionen består manuskonferensen numera $\mathrm{i}$ att en mindre grupp forskare får ansvar för att kommentera hela texten. Det följs sedan av en grönläsning där två personer ger rött eller grönt ljus för disputation. Det blir då viktigare hur man strategiskt väljer personer till manuskonferens och grönläsning. Då dessa viktiga steg blir mindre öppna minskar bredden i kommentarerna och därmed graden av kritisk reflektion. Detta leder till ett slags instrumentalisering som utgör ett hot mot uppfyllelsen av lärandemålet om kritiskt tänkande, menar denna intervjuperson (E).

En annan handledare, vilken vi ovan klassificerat som postpositivist, menar att examination av kritisk-teoretiska avhandlingar kräver lite mer av examinatorn. De som examinerar måste vara väl insatta i den vetenskapssyn de bygger på. Handledaren menar att det är en mer snårig och komplex litteratur som är aktuell om man har en subjektivistisk vetenskapssyn, att det krävs större kompetens och ett bredare förhållningssätt även i relation till andra discipliner (J). En annan person ser ett hot mot kritiskt tänkande i den ökade förekomsten av sammanläggningsavhandlingar, vilket inte ger utrymme för att diskutera alla led i forskningsprocessen ordentligt (L).

Förutom den egna institutionens examination av forskarutbildningens mål tecknar några av handledarna en annan utvärderingskontext som präglande för den enskilde doktoranden. Två hot mot kritiskt tänkande är enligt en handledare en alltför stor dominans av kvantitativ forskning samt en betoning på antalet publikationer i utvärdering av forskning (L). Tidskriftsbranschen som helhet ses som problematisk vad gäller kritiskt tänkande, kopplat i förlängningen till marknadens anspråk på att växa. Att splittra upp sina tankar på så många publikationer som möjligt skapar ett sätt att presentera forskarens idéer som inte gynnar kritiskt tänkande. Helheten i argumenteringskedjan går till exempel förlorad (L). En handledare påpekar i samma anda att det kan vara ett hot mot kritiskt tänkande att man måste skriva artiklar redan som doktorand för att räknas $(\mathrm{G})$. Farhågan delas av en annan handledare som ser en fara i att doktorander på grund av publiceringsstress tidigt anpassar sig till vad tidskrifter vill ha snarare än vad doktoranden själv vill diskutera. Doktoranden blir på så sätt indirekt styrd (D).

\section{Tidsramar och finansiering}

Många av handledarna lyfter fram möjliga hot mot kritiskt tänkande som de menar härrör från nationellt beslutade regelverk kring forskarutbildningen. Ett sådant hot är att för mycket styrning utövats via denna nivå, framför allt ifråga om tidsramar och finansiering. Reformen som innebär att doktorander ska bli klara på fyra-fem år ses av någon som ett hot mot kritiskt 
tänkande, vilket personen menar kräver mycket tid. Tidspress ger mindre utrymme för kritiskt tänkande och reflektion, det påverkar slutresultatet (A, E, M). Någon pekar på en byråkratisering av akademin med rapporteringskrav, krav på mätbara resultat - man blir mer tjänsteman än forskare (A). Största hotet mot kritiskt tänkande, menar en handledare, "stavas Carl Tham" som genom finansieringskrav och fyraårskravet snävade in förutsättningarna på ett sätt som leder forskningsprojekt i samma riktning. Kanske är det kortsiktigt instrumentellt bra ur ett samhällsperspektiv men för kritiskt tänkande är det knepigt eftersom det strömlinjeformar doktorandernas forskning. Handledaren framhåller att en rättighetskatalog för doktorander växt fram och successivt formaliserats, vilket nu skjuter över ansvaret till ett formellt regelverk. Även om formalisering och rättigheter har fördelar för doktoranden, kan det påverka utrymmet för självständighet och kritiskt tänkande genom minskad flexibilitet och ökad styrning av processen (E).

Flera handledare nämner att det kan vara problematiskt för främjandet av kritiskt tänkande att doktorander i allt högre grad antas till och finansieras av befintliga forskningsprojekt. Dessa projekt vilar på någon annans kritiska tänkande - inte doktorandens $(\mathrm{A}, \mathrm{M})$. Det ses också som ett problem för kritiskt tänkande om vi får in alltför många doktorander på projekt med frågor som försöker tillgodose forskningsfinansiärernas krav på policyrelevans (K). Kanske är det nödvändigt, men det blir inte en lika bra utbildning (A). Doktoranderna blir mer begränsade (B). En person, som enligt ovan ser på kritiskt tänkande enligt synsättet reflexiv självkritik, framhåller att det inte är så lätt att övertyga forskningsfinansiärer om avnämarnyttan av kritiskt tänkande. Det är skattemedel, de har sina ramar och regler - man får relatera till det. Då blir kritiskt tänkande mer av att man presenterar olika sätt att se, enligt denna handledare (C). Här sätts alltså policyrelevans i motsats till kritiskt tänkande.

Extern forskningsfinansiering är ett hot mot kritiskt tänkande om forskarna inte själva definierar vilka som är de viktiga forskningsfrågorna, utan låter forskningsråd göra det istället genom sina bedömningsprocesser (K). Dessa farhågor återfinns i Det hotade universitetet, i vilken författarna hävdar att det kortsiktiga utvärderande projekttänkandet möter sin raka motsats inom forskning och högre utbildning som har långsiktighet, fritt sökande och kritisk prövning som ledstjärnor. När projektidéer tävlar mot varandra i konkurrens om forskningsrådens pengar på forskningsmarknaden och "varumärket" blir det centrala, riskerar kritiska röster att tystas (Ahlbäck Öberg m.fl. 20I6). En intervjuperson hävdar att marknadslogiken har tillåtits gå för långt genom kommersialisering, instrumentalisering, linjestyrning mm. Vi är beroende av finansiärer i brist på basanslag, och finansiärerna efterfrågar problemlösande forskning. Detta värderas och premieras. Finansiärer vill ha tillämpad forskning, inte grundforskning. Om man strävar efter att lösa dagspolitiska problem såsom dessa redan formulerats minskar utrymmet för kritiskt tänkande. "Vi måste akta oss så inte universitetet blir ett lågbudget-konsultföretag. Då skulle folk tänka, varför ska jag ha 40 ooo och vara ofri när jag kan få 80 ooo på McKinsey och vara ofri, eller t.o.m. mer fri”. Denna handledare jämför forskares situation i Sverige med den i Danmark och menar att man i Danmark lyckats institutionalisera förutsättningar för kritiskt tänkande bättre genom mer basanslag till universiteten $(\mathrm{F})$.

\section{AVSLUTNING}

Kritiskt tänkande värderas högt av alla våra intervjupersoner. Vårt material visar att det finns några centrala komponenter i vad handledare på Statsvetenskapliga institutionen i Lund lägger 


\section{Magdalena Bexell \& Sara Kalm}

i begreppet kritiskt tänkande. Det rör sig kring skepsis och öppen granskning av forskningsprocessens alla element. Nästan lika vanligt är att i tillägg till detta betona självständighet och kreativitet som centralt för kritiskt tänkande. Dessa ses som fundamentala för alla oavsett forskningsinriktning och vetenskapsteoretisk position. Även de intervjupersoner som inledningsvis sade att de aldrig reflekterat över vad kritiskt tänkande var hamnade efter en stunds funderande i en kombination av dessa två. Men vi tror inte att detta är en institutionsspecifik samsyn, som har uppstått genom att kollegorna utgör en slags praxisgemenskap i Wenger-Trayner och WengerTrayners mening (2015). Det är mer sannolikt att det rör sig om en "doxa" (Bourdieu 2000: IO), alltså en grundläggande samsyn angående forskningens roll som präglar universitetsvärlden generellt, och kanske även samhället i stort (Fox 1994: 125). Våra intervjupersoner skiljde sig dock mycket åt ifråga om hur genomtänkt deras uppfattning om kritiskt tänkande var. Några visste inte att det är ett av målen för forskarutbildningen. Ett fåtal verkade ha ägnat ämnet en hel del uppmärksamhet och hade färdiga, internt sammanhängande, svar på våra frågor. Andra verkade aldrig ha reflekterat över det, något som de i flera fall sade rakt ut. Men under intervjuernas gång lyckades de i samtliga fall ringa in hur de tänkte. Vårt intryck är att de redan hade en latent uppfattning, som de blev medvetna om under det att intervjun pågick.

Bortom denna grundläggande samsyn går åsikterna mer isär. Vi har inte sett att subdisciplin har någon inverkan som förklaringsfaktor för dessa skillnader. Den generella samhällsvetenskapliga tillhörigheten påverkar nog mer än specifika inriktningar inom statsvetenskapen. Det finns anledning att tro att inställningen till kritiskt tänkande kan skilja sig åt mellan bredare akademiska fält, såsom samhällsvetenskap, naturvetenskap och humaniora. I en studie som liknar vår i angreppssättet fann Tim Moore (2013) att de rådande uppfattningarna om kritiskt tänkande inom humaniora kan beskrivas som: bedömning, skepsis, originalitet, sensibel textläsning, rationalitet, etiskt ställningstagande och självreflektion. I denna studie kom intervjupersonerna från historia, filosofi och kulturstudier, och deras humanistiska ämnesorientering avspeglades delvis i deras svar.

Vi tycker oss se att vetenskapsteoretisk orientering spelar en viktigare roll $i$ att förklara skillnader i synsätt bland våra intervjupersoner. För att belysa denna har vi använt oss av en enkel indelning i positivism respektive postpositivism. Det är enbart postpositivisterna som ger uttryck för synen att kritiskt tänkande innebär att avtäcka maktstrukturer, och att i sträng mening ifrågasätta kritikens egna grunder. Detta går i linje med denna forskningstraditions bredare ambition att "destabilisera" eller "förfrämliga" det som tas för givet i samhället, inklusive kunskapen själv. I kontrast till detta står positivisterna som i några fall talade om kritiskt tänkande i betydelsen "kritisk disposition" - något som involverar attityd och personlighet och växer fram genom en inre mognadsprocess, men där man alltså inte identifierar ett specifikt mål för utövandet av denna kritiska disposition.

Vi menar att förekomsten av olika definitioner av kritiskt tänkande inte behöver vara särskilt problematisk för forskarutbildningen. Det kan förvisso vara det i vissa sammanhang eftersom "kritiskt tänkande" återkommer som färdighetsmål för undervisningen på alla nivåer. Om inte vi som lärare, handledare och examinatorer har någon entydig uppfattning om begreppets innebörd blir det otydligt för doktorander vad vi eftersträvar och vad som ska examineras. Detta understryker behovet av att föra en diskussion om begreppet, men det gör det inte nödvändigt eller önskvärt att pådyvla handledare en gemensam definition. Att många tolkningar samexisterar beror på forskarnas och lärarnas egna vetenskapliga förhållningssätt, personligheter 
och preferenser, och kanske även i viss mån på bredden i universitetets uppdrag. Bevarandet av pluralism är tvärtom centralt för en samhällsvetenskaplig institution. Vår studie visar att det borde vara värt att explicitgöra vilka olika förhållningssätt som florerar för att öka kommunikationen och förståelsen mellan handledare och doktorand och handledare emellan.

Vad gäller kritiskt tänkande i forskarutbildningens praktik kunde vi inte se några tydliga skillnader relaterade till vetenskapsteoretisk position eller subdisciplin. Den position man intog ifråga om kritiskt tänkande i första delen av intervjun verkade inte heller ha någon avgörande inverkan. Vi noterar dock att flera handledare med långvarig lundabakgrund ser ökad formalisering och styrning av forskarutbildningens ramar som problematisk för doktorandens utveckling, med möjliga effekter bland annat på kritiskt tänkande. Detta togs inte upp av andra och kan kanske förklaras av att dessa handledare inte formats av samma institutionsmiljö i sin syn på vad styrning är, vilken grad av styrning som är önskvärd och vilka effekter styrning har. Utöver detta verkade det inte finnas några genomgående skiljelinjer. Här menar vi att det kan vara rimligt att tala om förekomsten av en praxisgemenskap, eller kanske snarast resterna av en sådan som förekommit tidigare vid institutionen.

Ett tydligt resultat är att alla intervjupersoner såg hot mot kritiskt tänkande, men att man betonade hot på olika nivåer. Några lyfte främst fram hot på institutionsnivån, t.ex. låg närvaro på seminariet och brist på debatt mellan företrädare för olika vetenskapsteoretiska paradigm. Andra betonade hot härrörande från den nationella och/eller internationella nivån. Formerna för finansiering, tidsramar, tendensen mot projektdoktorander, marknadisering och "publish or perish"pressen är exempel. Denna oro delas av många, även om den inte är lika framträdande hos alla. Vi har noterat att de som har ett synsätt på kritiskt tänkande som avtäcka maktstrukturer och/ eller reflexiv självkritik tenderade att placera sin diskussion om hot i en bredare kontext relaterad till styrande marknadslogiker.

Denna artikel har gett handledares syn på kritiskt tänkande och sammanfattat deras erfarenheter av hur kritiskt tänkande i forskarutbildningen kan se ut. Framtida undersökningar bör jämföra detta med doktoranders uppfattningar. En existerande studie om kritiskt och kreativt tänkande baserad på intervjuer med svenska doktorander indikerar nämligen att doktorander utvecklar defensiva strategier snarare än kritiska. Självkritik utifrån det egna ämnets normer var, i förebyggande syfte, ofta mer framträdande än kritiskt tänkande i andra bemärkelser (Brodin 20I6a). Kritiskt tänkande är ett ämne väl värt jämförande empiriska studier i framtiden eftersom det belyser centrala frågor om akademins roll och villkor i samhället.

\section{FÖRFATTARPRESENTATION}

Magdalena Bexell är docent i statsvetenskap vid Lunds universitet. Hennes forskning rör frågor om ansvar och legitimitet i internationellt samarbete kring hållbar utveckling. Hon undervisar på kurser i statsvetenskap, utvecklingsstudier och internationella relationer.

Sara Kalm är docent i statsvetenskap vid Lunds universitet. Hon forskar främst om migrationspolitik, medborgarskap och sociala rörelser, och hon undervisar i statsvetenskap och internationella relationer.

\section{LITTERATURFÖRTECKNING}

Ahlbäck Öberg, Shirin et al. (red), 2016. Det hotade universitetet. Stockholm: Dialogos förlag. Alvesson, Mats och Deetz, Stanley, 2000. Kritisk sambällsvetenskaplig metod. Lund: Studentlitteratur. 


\section{Magdalena Bexell \& Sara Kalm}

Ankarloo, Daniel och Friberg, Torbjörn, 20I2. ”Inledning”, i Ankarloo, Daniel och Torbjörn Friberg (red), Den högre utbildningen. Ett fält av marknad och politik. Möklinta: Gidlunds förlag, s. 7-2I.

Barnett, Ronald, 2015. "A Curriculum for Critical Being", s. 63-76 i Martin Davis och Ronald Barnett (red), The Palgrave Handbook of Critical Thinking in Higher Education. New York och Basingstoke: Palgrave Macmillan.

Booth, Ken \& Steve Smith (eds), 1995. International Relations Theory Today. Cambridge: Polity Press.

Bourdieu, Pierre, 200o. Pascalian Meditations. Stanford: Stanford University Press.

Bowell, Tracy och Gary Kemp, 2015. Critical Thinking: A Concise Guide, 4th Ed. London and New York: Routledge.

Broady, Donald, I988. "Kulturens fält. Om Pierre Bourdieus sociologi", s. 59-88 i Masskommunikation och kultur, NORDICOM-Nytt/Sverige, Nr I-2, 1988.

Brodin, Eva M., 20I6a. "Critical and creative thinking nexus: learning experiences of doctoral students", Studies in Higher Education, 41:6, s. 97I-989.

Brodin, Eva M., 20I6b. "Utveckling av kritiskt, kreativt och självständigt tänkande", s. I55-I92 i Eva Brodin, JitkaLindén, Anders Sonesson och Åsa Lindberg-Sand (red), Forskarhandledning i teori och praktik. Lund: Studentlitteratur.

Brookfield, Stephen, 20I5. "Speaking Truth to Power: Teaching Critical Thinking in the Critical Theory Tradition", s. 529-543 i Martin Davis och Ronald Barnett (red), The Palgrave Handbook of Critical Thinking in Higher Education. New York och Basingstoke: Palgrave Macmillan.

Brännström, Leila, 20II. "Kritikens läge", en intervju med Anders Johansson, Malin Rönnblom och Sharon Rider. Eurozine. Nedladdad via www.eurozine.com

Butler, Judith, 2009. "Critique, Dissent, Disciplinarity", Critical Inquiry 35, s. 773-795.

Cox, Robert W., I98I. "Social Forces, States and World Orders: Beyond International Relations Theory". Millennium: Journal of International Studies, IO: 2, pp. I26-155.

Croft, William \& D. Alan Cruse, 2004. Cognitive Linguistics. Cambridge: Cambridge University Press.

Curzon-Hobson, Aidan, 2003. "Higher Learning and the Critical Stance", Studies in Higher Education, 28:3, s. 2OI-2I2

Davies, Martin och Ronald Barnett,20I5. "Introduction”, s. I-25 i Davies, Martin och Ronald Barnett (red), 20I5. The Palgrave Handbook of Critical Thinking In Higher Education. New York och Basingstoke: Palgrave Macmillan.

Ennis, Robert H., 20I5. "Critical Thinking: A Streamlined Conception", s. 3I-48 i Martin Davis och Ronald Barnett (red), The Palgrave Handbook of Critical Thinking in Higher Education. New York och Basingstoke: Palgrave Macmillan.

Facione, Peter A., 1990. "Critical Thinking: A Statement of Expert Consensus for Purposes of Educational Assessment and Instruction, 'The Delphi Report". Nedladdad via: https://assessment.trinity.duke. edu/documents/Delphi_Report.pdf

Foucault, Michel, 20II. "Vad är kritik?", s. XXX i Fronesis, nr 36-37.

Fox, Helen, 1994. Listening to the world: Cultural issues in academic writing. Urbana: National Council of Teachers of English.

Geuss, Raymond, 2002. "Genealogy as Critique", European Journal of Philosophy, I0:2, s. 209-215.

Haas, Peter M., 1992. "Introduction: Epistemic Communities and International Policy Coordination", International Organization, 46:I, s. I-35.

Hasselberg, Ylva, 20I2. Vetenskap som arbete: normer och arbetsorganisation $i$ den kommodifierade vetenskapen. Möklinta: Gidlund.

Högskoleförordningen, Bilaga 2: Examensordningen, 1993. Svensk Författningssamling, 1993: IOO.

Högskolelagen, 1992. Svensk Författningssamling, I992: I434.

Kvale, Steinar, 1997. Den kvalitativa forskningsintervjun. Lund: Studentlitteratur.

Lakoff, George \& Mark Johnson, 1980. Metaphors We Live By. Chicago and London: Chicago University Press. 
Lapid, Yosef, 1989. "The Third Debate: On the Prospects of International Theory in a Post-Positivist Era", International Studies Quarterly, vol. 33, nr. 3, 235-234.

Moore, Tim, 20I3. "Critical thinking: seven definitions in search of a concept", Studies in Higher Education, 38:4, s. 506-522.

Rider, Sharon, Ylva Hasselberg och Alexandra Waluszewski (red), 2013. Transformations in Research, Higher Education and the Academic Market: The Breakdown of Scientific Thought. Dordrecht: Springer.

Siegel, Harvey, 1988. Educating reason: Rationality, critical thinking and education. New York: Routledge.

SOU 2015: 70. Högre utbildning under tjugo år. http://www.regeringen.se/contentassets/18fo7e408II34302a3c546341337cdff/hogre-utbildning-under-tjugo-ar-sou_20I5_70.pdf

Statsvetenskapliga institutionen Lund, 2016. Allmän studieplan för utbildning på forskarnivå i statsvetenskap (Dnr U 20I6/I). Tillgänglig på http://www.svet.lu.se/sites/svet.lu.se/files/allman-studieplanfou-statsvetenskap-I60204-sv.pdf

Statsvetenskapliga institutionen Stockholm, 20I5. Allmän studieplan för utbildning på forskarnivå i Statsvetenskap vid Stockholms universitet. Tillgänglig på http://www.statsvet.su.se/forskning/ utbildning-på-forskarnivå/regler-och-föreskrifter

Statsvetenskapliga institutionen Uppsala, 20I2. Allmän studieplan för utbildning på forskarnivå i statskunskap (SAMFAK 20II/I07). Tillgänglig på http://www.statsvet.uu.se/digitalAssets/399/c_399156-1_3-k_ allman-studieplan-forskarutbildning.pdf

Wenger-Trayner, Etienne och Wenger-Trayner, Beverly, 2015. "Communities of practice: a brief introduction”. http://wenger-trayner.com

BILAGA. Intervjupersoner

\begin{tabular}{llll}
\hline Intervjuperson & Metateori (P/PP) & Ämnesinriktning $(\mathbf{I P / P T / K P / F})^{*}$ & $\begin{array}{l}\text { Definition av kritiskt } \\
\text { tänkande(SG/KS/AM/RS)** }\end{array}$ \\
\hline A & PP & IP, PT & SG, KS \\
B & PP & IP & AM \\
C & PP & IP, PT & RS \\
D & P & IP, KP & KS, SG \\
E & P & PT & KS \\
F & PP & IP, PT & RS, SG \\
G & P & IP, KP & KS \\
H & P & KP & SG \\
I & P & KP & SG, KS \\
J & PP & IP & SG, KS, AM \\
K & P & KP & SG \\
L & PP & F, PT & AM, RS, SG \\
M & PP & IP & SG, KS \\
\hline
\end{tabular}

*IP= Internationell politik, $\mathrm{PT}=$ Politisk teori, $\mathrm{KP}=$ Komparativ politik, $\mathrm{F}=$ Förvaltning

** SG= Skepsis och granskning, $\mathrm{KS}=$ Kreativitet och självständighet, $\mathrm{AM}=$ Avtäcka maktstrukturer, $\mathrm{RS}=$ Reflexiv självkritik 